\title{
Distant Liver Metastases as a Major Factor Influencing Survival in Patients with Colorectal Cancer
}

\author{
Dimitar K. Penchev, Lilyana V. Vladova, Miroslav Z. Zashev, Radosvet P. Gornev \\ Department of General Surgery, Faculty of Medicine, Sofia University "St. Kliment Ohridski", Sofia, Bulgaria
}

Correspondence: D. Penchev, Department of General Surgery, Faculty of Medicine, Sofia University "St. Kliment Ohridski", Sofia, Bulgaria

E-mail: d.k.penchev@gmail.com Tel. +359887291333

Received: 20 Sep 2015

Accepted: 20 June 2016

Published Online:13 Aug 2016

Published: 30 Sep 2016

Key words: liver metastatic disease, colorectal cancer survival

Citation: Penchev DK, Vladova LV, Zashev MZ, Gornev RP. Distant Liver Metastases as a Major Factor, Influencing Survival in Patients with Colorectal Cancer.

Folia Medica 2016;58(3);182-187, doi: 10.1515/folmed-2016-0023
Aim: To assess the effect of the factor 'hepatic metastatic disease' on long-term outcomes in patients with colorectal cancer.

Materials and methods: We analysed retrospectively 200 randomly selected patients. Forty-two of them were excluded from the study for different reasons so the study contingent was 158 patients over a period of 23 years. All were diagnosed and treated in the Lozenetz University Hospital, in the Department of General Surgery. 125 of the patients were diagnosed with colorectal cancer without distant metastases and 33 of the patients had liver metastases as a result of colorectal carcinoma. The statistical analysis was performed using SPSS 19 IMB, with a level of significance of $\mathrm{P}<0.05$ at which the null hypothesis is rejected. We also used descriptive analysis, Kaplan-Meier estimator, Log-Rank Test and LifeTable statistics models.

Results: The median survival for patients without metastases was 160 months, and the median was 102 months. The median survival for patients with liver metastases was 28 months and the median was 21 months. One-year survival for patients without metastases was $92 \%$ versus $69 \%$ in patients with liver metastases.

Conclusion: Average, annual and median survivals are influenced statistically significantly by the presence of liver metastases compared to overall survival and that of patients without metastatic colorectal cancer. Liver metastatic disease is a proven factor affecting long-term prognosis and survival in patients with colorectal cancer.

\section{INTRODUCTION}

Metastatic progression of cancer diseases is a major factor affecting survival in patients with neoplastic diseases. ${ }^{1}$ Colorectal cancer (CRC) is not an exception in this regard. Given the extremely high frequency which keeps increasing recently and the great many cases of late-diagnosed patients with advanced stage of cancer with distant dissemination, it is absolutely necessary that in-depth research in the treatment of metastatic colorectal cancer be carried out. ${ }^{2}$ As the main location of distant metastatic process is the liver, it has become very common in the surgical community to refer to this condition as 'hepatic metastatic disease' (HMD). ${ }^{3}$ That requires a thorough examination of the treatment options and outcomes for patients with colorectal cancer and HMD. In recent years, many authors have analyzed a number of factors affecting distant outcomes of patients with colorectal cancer, suggesting that the major ones can be the stage of the disease and the presence of liver metastases. ${ }^{4}$
The progress of modern oncology enabled multidisciplinary approach to patients who have HMD with very good long-term results. ${ }^{5}$

\section{AIM}

To assess the impact of HMD on long-term outcomes in patients with colorectal cancer.

\section{MATERIALS AND METHODS}

The present retrospective study included 200 randomly selected patients. Forty-two of them were excluded because of unspecified metastasis (9 patients) and distant metastasis with various liver localization (33). Between 1990 and 2013 this study recruited 158 patients diagnosed with colorectal cancer and followed them up until 10.03.2014. The median follow-up was 62 months. The data for this clinical study were collected from the National Cancer Registry of the Republic of Bulgaria. The patients were diagnosed and surgically treated at the Lozenetz University Hospital. Of these patients, 
125 were diagnosed with colorectal cancer without distant metastases and 33 had colorectal cancer and liver metastases both treated surgically. The statistical analysis was performed using SPSS (IBM). ${ }^{19}$ The level of significance was set at 5\% $(\mathrm{P}<0.05)$ in all analyses. Descriptive statistical methods were used; the qualitative variables between the groups were compared by $\chi^{2}$ test; the quantitative variables were compared by t-test for independent samples, Kaplan-Meier estimator, life tables and log rank analysis.

\section{RESULTS}

Table 1 presents the main demographic parameters of the two groups of patients - HMD, as a consequence of CRC and non-metastatic CRC. We found no significant differences between the groups in the main demographic characteristics $(\mathrm{P}>0.05)$. Twenty-one of 33 patients with hepatic metastatic colorectal cancer had a single lesion in hemiliver, 4 of the patients had multiple lesions in hemiliver, and 8 of the examined patients had multiple lesions disseminated throughout the liver.

We determined the expected average and median survival presented with standard deviation and 95\% confidence intervals (CI). Using the log-rank test we found that there was a significant difference in the expected average and median survival $(\mathrm{P}<0.001)$ between patients with hepatic metastatic disease and non-metastatic CRC. Fig. 1 shows the function of survival comparing the two treatment groups (patients with HMD and non-metastatic colorectal cancer). The median survival in patients without metastasis was $160 \pm 15$ months, with a confidence interval CI [131-190] months and the median was $102 \pm 2$ with median confidence interval CI [81-123] months. The median survival in patients with liver metastasis was $28 \pm 6$ months with a confidence interval CI [16-39] months and the median was 21 \pm 3 months with a median confidence interval CI [15-28] months.

In order to determine the year survival rate we used the life-table analysis (Fig. 2). One-, two-, three- and five-year survival was statistically significantly different between the two groups, $\mathrm{P}<0.01$ for the first, second and third year and $\mathrm{P}<0.01$ for the five-year survival.

\section{DISCUSSION}

Colorectal cancer is the most common neoplasm in the digestive system and the second most frequent of all cancers. ${ }^{6}$ For its part, HMD is a major factor,
Table 1. Demographic characteristics

\begin{tabular}{lcc}
\hline \multicolumn{1}{c}{$\mathbf{N = 1 5 8}$} & $\begin{array}{c}\text { NMCRC } \\
\text { N=125 }\end{array}$ & $\begin{array}{c}\text { HMD } \\
\text { N=33 }\end{array}$ \\
\hline Age - (Mean \pm SD) & $65 \pm 10$ & $63 \pm 11$ \\
$\begin{array}{l}\text { Sex - Men/Women } \\
\text { (number) }\end{array}$ & $84 / 45$ & $22 / 11$ \\
$\begin{array}{l}\text { Concomitant diseases \% } \\
\text { BMI }=\text { weight }(\mathrm{kg}) /\end{array}$ & $78 \%$ & \\
height $^{2}(\mathrm{~m})(\mathrm{Mean} \pm \mathrm{SD})$ & $25 \pm 5$ & \\
& & \\
\hline
\end{tabular}

SD - Standard Deviation

BMI - Body Mass Index

NMCRC - Non-metastatic colorectal cancer

HMB - Hepatic metastatic disease

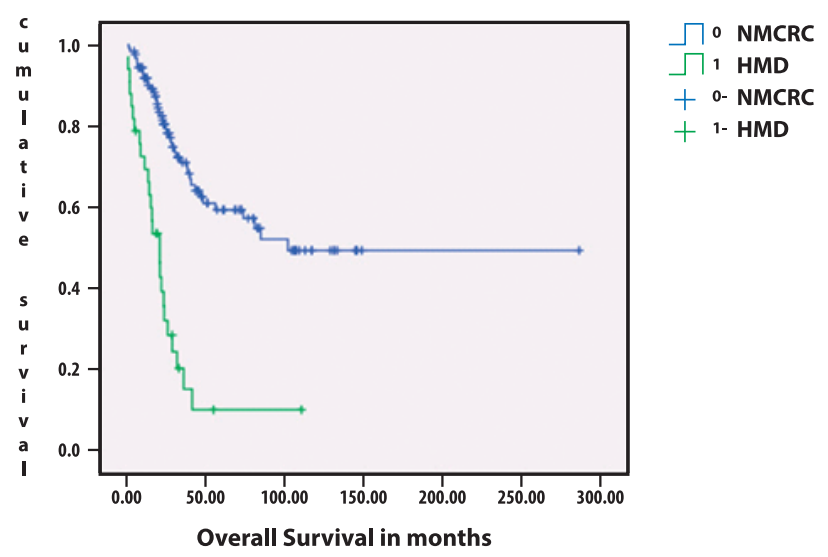

Blue ,,+“- NMCRC ("Censored”)

Green „,"“ - HMD (“Censored”)

Figure 1. Survival rate, $\mathrm{n}=158$.

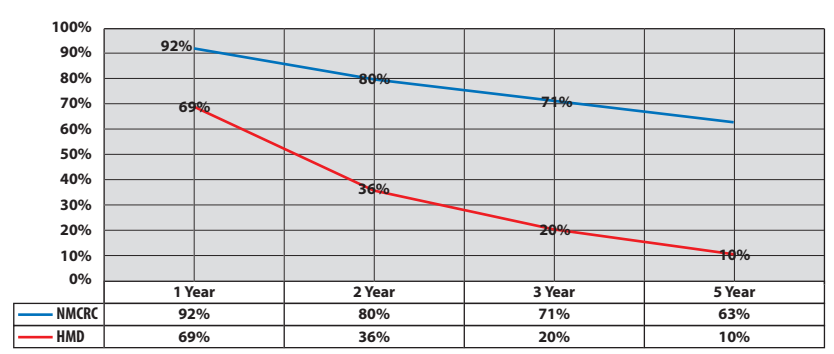

Figure 2. Life table of survival rate, $n=158$. 
associated with survival of patients with colorectal cancer. ${ }^{1}$ In the present study, comparing patients with liver metastatic disease (surgically treated) and those without, we found no significant differences in terms of sex, age, body mass index and the presence of co-morbidity. Surgical treatment is still the main pillar in the treatment of HMD. ${ }^{7}$ Progress and establishment of various innovative methods for its application in modern oncology reflects on distant results. ${ }^{8}$ In the last 20 years new criteria for resectability of liver lesions have been accepted increasing the volume of resectable liver metastases. ${ }^{9}$ This in turn improved the prognosis of patients with end-stage colorectal cancer. ${ }^{10}$ In the group of patients with HMD the cases with single liver lesions were predominant. This trend is due to early detection of metastatic process as a result of the progress of diagnostic imaging methods. ${ }^{11}$ Most of the patients (92\%) in our study underwent liver resection; $23 \%$ of these were abnormal liver resections. A large part of them as tumorectomy - $10 \%$ and $59 \%$ - typical liver resections, most often sectorectomy and hemiliverectomy. In recent years, the method of radiofrequency ablation has become a quite often used surgical modality - we applied it only for a few patients with unresectable HMD. ${ }^{8}$ Strang and co-authors highlighted a number of advantages in the treatment of unresectable liver metastases with radiofrequency ablation. Operative intervention in the liver is extremely precise, according to the general condition of patients, remaining liver parenchyma and the possibility of radicalism of the intervention. ${ }^{12}$ Speaking of distant results, it is appropriate to discuss the results of the total patient population, including patients with liver metastases and without metastases. Their median survival at first glance seems encouraging, but considering that few cases distort the statistical model of survival, median survival rate should be used as a reliable method for determining the prognosis. As for the tested two groups - patients without metastases and those with liver metastases, there is a significant difference in the mean and median survival. On the background of the long follow-up period (23 years) and the fact that many of the patients have undergone treatment different from current chemotherapy, radiotherapy and comparing results to global trend, results show better survival in both groups, as a result to multidisciplinary approach to the oncological disease. ${ }^{13,14}$ Ghazali et al. determined the influence of various factors associated with the prognosis of patients with CRC, announcing similar year survival in non-metastatic colorectal cancer stages I-III. Stage and presence of metastases were identified as independent factors influencing the prognosis of patients with colorectal cancer by number of authors such as Ferrand et al. Furthermore, several other factors influence the survival rate - both medical (stage, co-morbidity, lymphatic infiltration, local status, etc.), and social (access to oncology center, personal desire for treatment, etc.). ${ }^{15,16}$ The development of chemotherapy and radiotherapy, and in particular the treatment of HMD also affects the evolution and outcome of the disease. ${ }^{17,18}$ Evaluated by $95 \%$ confidence interval, average and median expected survival were statistically significantly higher in patients with non-metastatic colorectal cancer. This is a valuable method for determining the expected survival for patients which is based on the stage of the disease. ${ }^{19}$ Kumar et al. highlight the advantages of the method and define HMD as a major factor influencing the prognosis of patients with colorectal cancer. All these results form HMD as a major factor of survival and distant prognosis in patients with colorectal cancer. Proof of this is the conducted Log Rank (Mantel-Cox)-test with a high level of significance determining statistically significant difference between year survival in patients with HMD and those without metastatic process. The difference between the two groups at any interval is statistically significant and determines a better prognosis of patients without metastatic process. ${ }^{20,21}$ Khattak et al. conducted a study based on the Australian Cancer Registry, linked with advanced colorectal cancer and the differences between metastatic and non-metastatic CRC. Using life table analysis they determine the metastatic process as a major factor affecting survival in patients with colorectal cancer. Compared to results from other centers around the world, these are good results for the time of follow-up of the patients. ${ }^{19,22}$ In the final stage, patients with HMD have a relatively better prognosis after a therapeutic treatment. ${ }^{23}$ Lordan and co-authors conducted a 10-year follow-up of patients after radical resection of liver with HMD in patients with colorectal cancer, and reported excellent results, better prognosis and improved median survival based on a multidisciplinary approach to the disease. These results set a different attitude, towards patients with liver metastases. Apart from these poor prognosis patients have a higher risk of recurrence, as well as the underlying disease and the HMD. ${ }^{24,25}$ This requires that patients with HMD should be included in a program with inten- 
sive follow-up, as are the recommendations of the National Board of Oncology. ${ }^{26}$ Regular study of tumor markers and implementation of radiological methods provide adequate control of the disease and improve survival. ${ }^{27}$ This is especially important for the multidisciplinary approach and therapeutic (surgical, chemotherapy and radiotherapy) behavior in patients with HMD that provides a better longterm prognosis. ${ }^{28,29}$ Langenhoff et al. reported a higher risk of recurrence in patients after radical resection of liver metastases due to colorectal carcinoma and analyze similar measures, necessary to monitor patients after radical treatment of HMD.

\section{CONCLUSIONS}

HMD makes the prognosis of patients with colorectal cancer significantly worse. The average and median survival and one-, two-, three- and five-year survival rate are influenced on the presence of liver metastases, compared with overall survival of patients without metastatic process. Hepatic metastatic disease is a proven independent factor influencing the long-term prognosis in patients with colorectal cancer. Despite the progress of oncology, the prognosis for patients with HMD remains unsatisfactory and requires hard work of surgeons and oncologists, as well as the implementation of early diagnosis and screening for colorectal cancer.

\section{REFERENCES}

1. Duraker H, Çaynak Z, Hot S. The impact of primary tumor resection on overall survival in patients with colorectal carcinoma and unresectable distant metastases: A prospective cohort study. International Journal of Surgery 2014;12(7):737-41.

2. Dimitrova N. Colon (C18,ICD10) In: Dimitrova N, Vukov M, Valerianova Z .Cancer incidence in Bulgaria 2011. Volume XXII. Paradigma"2013";2013:56.

3. Mantke R, Schmidt U, Wolff S, et al. Incidence of synchronous liver metastases in patients with colorectal cancer in relationship to clinico-pathologic characteristics. Results of a German prospective multicentre observational study. European Journal of surgical oncology 2012;38(3):259-65.

4. Lee J, Jeon J, Maverhardt J. Diet and Lifestyle in Survivors of Colorectal Cancer. Hematology/Oncology Clinics of North America 2015;29(1):1-27.

5. Velde CJH, Boelens PG, Tains PJ, et al. Experts reviews of the multidisciplinary consensus conference colon and rectal cancer 2012: science, options and experiences from the experts of surgery. EJSO 2014;40(4):454-68.

6. Thosani N, Guha S, Singh H. Colonoscopy and
Colorectal Cancer Incidence and Mortality. Gastroenterology Clinics of North America 2013;42(3): 619-37.

7. Hao CY, Ji JF. Surgical treatment of liver metastases of colorectal cancer: Strategies and controversies in 2006. EJSO 2006;32(5):473-83

8. Strang A, Fischbach R, Teichmann W, et al. A systematic review on clinical benefit and role of radiofrequency ablation as treatment of colorectal liver metastases. EJC 2009;45(10):1748-56.

9. Pawlik TM, Schulick RD, Choti MA. Expanding criteria for resectability of colorectal liver metastases. Oncologist 2008;12:51-64.

10. Slotta JE, Schuld J, Distler S, Richter S, Schilling MK, Kollmar O. Hepatic resection of non-colorectal and non-neuroendocrine liver metastases - survival benefit for patients with non-gastrointestinal primary cancers - a case-controlled study. Int J Surg 2014;12(2):163-8.

11. Albercht MH, Wichmann JL, Muller C, et al. Assessment of colorectal liver metastases using MRI and CT: Impact of observer experience on diagnostic performance and inter-observer reproducibility with histopathological correlation. Eur J Radiol 2014;83(10):1752-8.

12. Jones RP, Hamann S, Malik HZ, Fenwick SW, et al. Defined criteria for resectability improves rates of secondary resection after systemic therapy for liver limited metastatic colorectal cancer. Eur J Cancer 2014;50(9):1590-1601.

13. Ghazali AK, Musa KI, Naing NN, et al. Prognostic Factors in Patients With Colorectal Cancer at Hospital University Sains Malaysia. Asian J Surg 2010;33(3):127-33.

14. Ferrand F, Malka D, Bourredjem A, et al. Impact of primary tumour resection on survival of patients with colorectal cancer and synchronous metastases treated by chemotherapy: Results from the multicenter, randomised trial Fédération Francophone de Cancérologie Digestive 9601. Eur J Cancer 2013;49(1):90-7.

15. Kelsall HL, Baglietto L, Muller D, et al. The effect of socioeconomic status on survival from colorectal cancer in the Melbourne Collaborative Cohort Study. Social Science \& Medicine 2000;68(2):290-7.

16. Tong L, Ahn C, Symanskit E, et al. Relative impact of earlier diagnosis and improved treatment on survival for colorectal cancer: A US database study among elderly patients. Cancer Epidemiology 2014;38(6):733-40.

17. Benavides M, Pericay C, Auerbes MV, et al. Oxaliplatin in Combination With Infusional 5-Fluorouracil as First-Line Chemotherapy for Elderly Patients With Metastatic Colorectal Cancer: A Phase II Study of the Spanish Cooperative Group for the Treatment 
of Digestive Tumors. Clinical Colorectal Cancer 2012;11(3):200-6.

18. Munoz P, Urien MA, Ravina AR. Efficacy and safety of intraoperative radiotherapy in colorectal cancer: A systematic review. Cancer Letters 2011;306(2): 121-33.

19. Kumar R, Price TJ, Beeke C, et al. Colorectal cancer Survival: An analysis of Patients With Metastatic Disease Synchronous and Metachronous With the Primary Tumor. Clinical Colorectal Cancer 2014;13(2):87-93.

20. Lordan JT, Karanjia ND, Quiney N, et al. A 10year study of outcome following hepatic resection for colorectal liver metastases - the effect of evaluation in a multidisciplinary team setting. EJSO 2009;35(3):302-6.

21. Khattak M, Martin HL, Beeke C, et al. Survival Differences in Patients With Metastatic Colorectal Cancer and With Single Site Metastatic Disease at Initial Presentation: Results From South Australian Clinical Registry for Advanced Colorectal Cancer. Clinical Colorectal Cancer 2012;11(4):247-54.

22. Kishiki T, Masaki T, Matsuoka H, et al. Modified Glasgow prognostic score in patients with incurable stage IV colorectal cancer. The American Journal of Surgery 2013;206(2):234-40.

23. Nordlinger B, Custem EV, Rougier P, et al. Does chemotherapy prior to liver resection increase the potential for cure in patients with metastatic colorec- tal cancer? A report from the European Colorectal Metastases Treatment Group. European Journal of Cancer 2007;43(14):2037-45.

24. Erning FN, Steenbergen LN, Lemmens VEPP, et al. Conditional Survival for long-term colorectal cancer survivors in the Netherlands: who do best? EJC 2014;50(10):1732-9.

25. Leblanc F, Fonck M, Brunet R, et al. Comparison of hepatic recurrences after resection or intraoperative radiofrequency ablation indicated by size and topographical characteristics of the metastases. European Journal of Surgical Oncology (EJSO) 2008;34(2):185-90.

26. Langenhoff BS, Krabbe PF, Ruers TJ. Efficacy of follow-up after surgical treatment of colorectal liver metastases. European Journal of Surgical Oncology (EJSO) 2009;35(2):180-6.

27. Maslyankov S, Penchev D, Fidoshev I. Correlation between serum levels and pathologic stages of tumor markers used in colorectal carcinoma. Journal MD 2014;4 (82):79-82 (Bulgarian).

28. Wallace K, Streba KR, Gore E, et al. Prognostic Factors in Relation to Racial Disparity in Advanced Colorectal Cancer Survival. Clinical Colorectal Cancer 2013;12(4):287-93.

29. Duduv A, Koleva M. Follow-up in colorectal cancer - evidence based medicine. Kalev D. Uchebna Kniga 2011, Clinical behavior in colorectal and anal cancer. MOPE 2011:37-8 (Bulgarian).

\section{Дальние метастазы в печени как основной фактор, оказывающий влияние на выживание пациентов с колоректальным раком}

\section{Димитр К. Пенчев, Лиляна В. Владова, Мирослав 3. Зашев, Радосвет П. Горнев}

Кафедра общей хирургии, Медицинский факультет, Софийский университет им. Св. Климента Охридского, София, Болгария

\section{Для корреспонденции: Димитр Пенчев, Кафедра общей хирургии, Медицинский факультет, Софийский университет им. Св. Климента Охридского, София, Болгария \\ E-mail: d.k.penchev@gmail.com тел. +359887291333}

Дата получения: 20.09.2015 г. Дата приемки: 20.07.2016 г. Дата онлайн публикации:13.08.2016 г. Дата публикации: 30.09.2016 г.

\section{Ключевые слова:} метастатическое поражение печени, выживание в случаях колоректального рака
Цель: Анализ влияния фактора "метастазы в печени" на долгосрочный исход заболевания у пациентов с колоректальным раком.

\begin{abstract}
Материалы и методы: При проведении этого ретроспективного исследования было проанализировано 200 произвольно выбранных пациентов. Сорок два пациента были исключены из исследования, которое включало наблюдение за 158 пациентами в течение 23 лет. Всем им был поставлен диагноз и проведено лечение в отделении общей хирургии Университетской больницы "Лозенец". У 125 пациентов был диагностицирован колоректальный рак без дальних метастазов, а у 33 пациентов были обнаружены метастазы в печени, появившиеся в результате колоректальной карциномы. В целях статистического анализа использована программа IBM SPSS 19, а с уровнем значимости, исключающим нулевую гипотезу, было выбрано $\mathrm{P}<0.05$. В исследовании были использованы метод Каплана-Мейера, логранговый тест, таблицы смертности и описательные статистические модели.
\end{abstract}

Результат: Медианный показатель выживания пациентов без метастазов со- 
Цитаты: Пенчев Д.К., Владова Л.В., Зашев М.З., Горнев Р.П. Дальние метастазы в печени как основной фактор, оказывающий влияние на выживание пациентов с колоректальным раком.

Журнал "Folia Medica" 2016;58(3);182-187, doi: 10.1515/folmed-2016-0023 ставил 160 месяцев, а медиана - 102 месяца. Медианный показатель выживания пациентов с метастазами в печени составил 28 месяцев, а медиана - 21 месяц. Однолетнее выживание пациентов без метастазов составило 92\%, а пациентов с метастазами в печени - 69\%.

Заключение: Средний, годовой и медианный показатель выживания находится в статистически значимой зависимости от наличия метастазов в печени по сравнению с общим показателем выживания и показателем выживания пациентов без метастатического колоректального рака. Метастазы в печени являются доказанным фактором, оказывающим влияние на долгосрочный прогноз и выживание пациентов с колоректальным раком. 